\title{
Tradução dos capítulos 2 e 6 do Tomo II (Suplementos) de $O$ mundo como vontade e como representação
}

\author{
Dax Moraes \\ Professor no Curso de Filosofia da Universidade do Estado do Rio Grande do Norte (CaC/UERN), \\ Doutor em Filosofia pela Universidade Federal do Rio Grande do Norte (UFRN). \\ E-mail: oejeblik@yahoo.com.br
}

$[22]^{1}$ CAPÍTULO 2

\section{PARA A DOUTRINA DO CONHECIMENTO INTUITIVO, OU DO ENTENDIMENTO}

Em toda idealidade transcendental o mundo objetivo conserva uma realidade [Realität] empírica: contudo, o objeto não é coisa em si; mas é real [real] enquanto objeto empírico ${ }^{2}$. Entretanto, o espaço somente é em minha cabeça; mas minha cabeça no espaço é empírica ${ }^{3}$. A lei da causalidade, aliás, jamais pode servir para eliminar o Idealismo, formando uma ponte entre as coisas em si e nosso conhecimento delas e, por conseguinte, no efeito de seu emprego, assegurando a realidade absoluta do mundo que se apresenta: mas isto de maneira alguma suspende a relação causal dos objetos entre si, nem aquela incontestavelmente reconhecida entre cada corpo próprio e os demais objetos materiais ${ }^{4}$.

\footnotetext{
${ }^{1}$ A numeração entre colchetes corresponde à paginação da terceira edição das obras completas de Arthur Schopenhauer primeiramente editadas por Frauenstädt, em seis volumes: Arthur Schopenhauer's Sämmtliche Werke. Ed. Julius Frauenstädt. Leipzig: Brockaus, 1877. Também foi consultada, em busca de eventuais correções e atualização ortográfica, a Arthur Schopenhauers Sämtliche Werke em doze volumes, Stuttgart.

${ }^{2}$ Trata-se de uma afirmação fundamental à compreensão da doutrina da representação de Schopenhauer. Aqui se exprime a recusa a toda forma de realismo, já expressa em sua Dissertação sobre a quádrupla raiz do princípio de razão suficiente. $\mathrm{O}$ real diz respeito à representação, ao objeto da experiência, não à coisa em si, de modo que toda realidade (Realität) é transcendentalmente ideal, o que tem por consequência a afirmação de que toda intuição é intelectual (v. WWV I/MVR I, §§ 4-5).

${ }^{3}$ A sentença de Schopenhauer - Zwar ist der Raum nur in meinem Kopf; aber empirisch ist mein Kopf im Raum - motiva uma tradução radical, explicitando um aparente paradoxo: o espaço, enquanto forma da intuição, está na minha cabeça, não na coisa em si; por sua vez, minha cabeça, enquanto objeto empírico real, é representada no espaço (que ocupa), ou seja, minha cabeça está no espaço que está em minha cabeça, onde se situam todos os objetos da experiência enquanto objetos. Apenas empiricamente minha cabeça é alguma coisa e, como toda experiência supõe intuição espacial, é o espaço em "minha cabeça" que a coloca "no espaço" representado como exterior. (cf. WWV I/MVR I, §§ 5-6)

${ }^{4}$ Crítico das doutrinas racionalistas defensoras do que se convencionou denominar "intuição intelectual” - expressão a que, a propósito, Schopenhauer chegará a atribuir novo significado -, também recusa o empirismo materialista como alternativa. Defender que o fato de se testemunhar relações causais entre objetos e entre estes e o cérebro explica a origem do conhecimento ou a realidade essencial das coisas não suprime a idealidade transcendental da própria lei da causalidade, já implícita em toda experiência possível - trata-se, segundo o próprio Schopenhauer, de uma petição de princípio. Além disso, parte do pressuposto equivocado de diferenciar objeto e representação (cf. WWV I/MVR I, § 5; v. tb. § 7). Por outro lado, ou por isso mesmo, a lei da causalidade nos é dada em toda realidade. Desse modo, é no mínimo ingênuo lançar mão da causalidade natural para se refutar o intelectualismo dizendo que todo conhecimento se origina nas sensações. $O$ uso ilegítimo da lei da causalidade consiste na pretensão de, recorrendo-se a ela, ultrapassar o conhecimento de fenômenos, ou seja, estabelecer uma "ponte" entre nossas representações e as coisas em si mesmas tomando-as por "objetos em si", independentes do sujeito.
} 
Mas a lei da causalidade somente liga os fenômenos, não os ultrapassa. Somos e permanecemos com eles no mundo dos objetos, isto é, dos fenômenos ou, dito propriamente, das representações. Todavia, [23] sendo assim necessário somente o fenômeno e não havendo direito para se aplicar [a lei da causalidade] ao mundo das coisas em si mesmas, a totalidade de tal mundo da experiência permanece primeiramente pelo conhecimento de um sujeito, sua condição necessária, e então causado pelas formas especiais de nossa intuição e nossa apreensão. Até o sujeito ele mesmo (uma vez que só ele é cognoscente) pertence apenas ao fenômeno de cuja totalidade constitui a outra metade ${ }^{5}$.

Sem a aplicação da lei da causalidade não se poderia entrementes vir à intuição um mundo objetivo: pois essa intuição é, como frequentemente salientei, essencialmente intelectual e não simplesmente sensível ${ }^{6}$. Os sentidos dão simplesmente sensações, que ainda estão muito distantes das intuições. Locke distinguiu na intuição a porção das percepções sensoriais sob o nome de qualidades secundárias, que ele com razão negou às coisas em si mesmas. Mas Kant, levando mais longe o método de Locke, distinguiu, além disso, e negou às coisas em si, o que é pertinente ao beneficiamento ${ }^{7}$ daquela matéria (percepções sensoriais) pelo cérebro, e daí resultou que tudo aquilo que Locke deixou às coisas em si como qualidades primárias, a saber, extensão, figura, solidez etc., eram conceitos, graças a que,

\footnotetext{
${ }^{5}$ Em resumo, o sujeito é a condição do objeto intelectual, diferente do objeto imediato (i.e. o próprio corpo) que se encontra objetivamente dentre outros objetos no mundo dos fenômenos, nele existente segundo as formas que condicionam o conhecimento; enquanto cognoscente, o sujeito é contrapartida do conhecido (seu objeto) e, assim, incognoscível e distinto de toda representação de um "eu”. A causalidade é então posta pelo sujeito e por ele reconhecida, de modo que toda necessidade causal diz respeito tão-somente aos fenômenos representados, em nada concernente às coisas em si. A pertinência do sujeito ao mundo fenomênico, portanto, não deve ser interpretada como um fazer parte do conjunto dos objetos, mas em ser a ele subjacente a priori. Uma vez que apenas os objetos agem uns sobre os outros enquanto sujeitos à causalidade, o objeto imediato é o simples meio pelo qual o sujeito pode perceber objetos em geral segundo as conexões entre o cérebro e os sentidos, imperceptíveis em si e por si mesmos, justamente porque não há mediação entre o sujeito e o próprio corpo. (v. WWV I/MVR I, $\S \S 2 / 6$ )

${ }^{6}$ V. nota 4. Mundo objetivo significa mundo real, porém não no sentido do realismo, como entidade independente do sujeito. Sendo assim, a intuição que se tem do mundo objetivo é intelectual, pois intelectuais são seus objetos, não coisas em si independentes de nossas faculdades cuja percepção dependesse apenas dos sentidos. É graças ao intelecto que os sentidos desempenham seu papel mediador e este se torna possível, mas sempre condicionado. Os sentidos não pensam, como alguns filósofos chegaram a defender - v. mais adiante -; a pura sensação não produz representação alguma na medida em que as formas de toda representação são intelectuais, de modo que é no cérebro que aparecem, não nos órgãos sensoriais. Isto, contudo, não conduz a um solipsismo como habitualmente se interpreta, pois o próprio sujeito se constitui na relação cognitiva com objetos, de modo que o "intelectualismo" schopenhaueriano não se resolve nisto. As doutrinas da intuição intelectual que a estimam como capaz de apreender coisas em si ou produzir imagens alheias a ela são, portanto, falsas. Em síntese, a afirmação schopenhaueriana de que há apenas intuições intelectuais significa que todo objeto conhecido é representação de um intelecto. Assim, Schopenhauer, radicalizando o idealismo transcendental, supera o sensualismo empirista - derrubando, pois, seu potencial cético - e o próprio intelectualismo realista, ou idealismo absoluto, como fica claro a seguir. Após a breve retomada de algumas teses lançadas nos §§ 1-7 do primeiro tomo, tratando fundamentalmente da forma originária do mundo como representação - i.e. ser objeto para um sujeito -, tem início aqui a parte original e propriamente dita suplementar, começando por uma mais pormenorizada crítica da tradição mais recente enfatizando-se as relações entre os sentidos, o cérebro e o entendimento.

${ }^{7} \mathrm{O}$ termo "beneficiamento" procura traduzir, aqui como em passagens subsequentes, o alemão "Verarbeitung" mantendo a conotação de que se trata de um processo pelo qual a matéria-prima do conhecimento, os dados sensíveis na intuição, depois de conformados às formas a priori de tempo e espaço e à lei da causalidade, passam pelo processo de abstração, pelo qual tal matéria é como que transformada e adequada pelo intelecto humano de modo a ser representada por conceitos. Assim, por "beneficiamento" pretende-se indicar o caráter produtivo-transformador do conhecimento humano mediante os dados sensíveis em que se sustenta.
} 
em Kant, a coisa em si se torna um " $\mathrm{x}$ " totalmente desconhecido ${ }^{8}$. Em Locke, por conseguinte, a coisa em si é algo incolor, sem ruído, inodoro, insípido, nem quente nem frio, nem macio nem duro, nem liso nem áspero; todavia permanece algo extenso, figurado, impenetrável, em repouso ou em movimento, dotado de medida e número. Em Kant, porém, ela teve também todas estas últimas propriedades postas de lado; porque somente por meio de tempo, espaço e causalidade ${ }^{9}$ elas são possíveis, mas apenas em nosso intelecto (cérebro) ${ }^{10}$ surgem assim, como cores, sons, odores etc. nos nervos dos órgãos sensoriais. A coisa em si, em Kant, se tornou não-espacial, inextensa, incorpórea. O que então está aí no mundo objetivo, os sentidos fornecem para a intuição na proporção do que para isto fornece a função cerebral (espaço, tempo, causalidade), como na proporção da massa dos nervos sensoriais para a massa cerebral, depois da extração $[\mathrm{Abzug}]$ daquelas outras partes empregadas pelo pensamento propriamente dito $^{11}$ [eigentlichen Denken], isto é, as representações abstratas, e que portanto escapam aos animais.

\footnotetext{
${ }^{8}$ Locke, no segundo capítulo do livro IV do Ensaio acerca do entendimento humano, define a intuição como o grau primeiro e imediato de conhecimento, logo, o mais perfeito, compreendendo-a como a percepção imediata do acordo ou desacordo de duas ou mais ideias. No entanto, essas ideias, conforme exposto já no livro II, são previamente impressas na mente graças a percepções sensoriais. A percepção, por sua vez, depende de que a mente note a impressão sensível, conforme se lê no capítulo IX do livro II. Desse modo, os sentidos não produzem conhecimento por si sós. No segundo capítulo deste livro, Locke defende que as qualidades correspondentes às ideias simples estão nas próprias coisas que nos afetam; afinal, sem elas, uma vez que a mente não produz ideias a partir do nada, não há ideias que permitam qualquer conhecimento intuitivo e as operações que viabilizam a combinação de ideias simples em ideias complexas ou mesmo a quádrupla raiz de toda intuição de acordo ou desacordo: identidade ou diversidade, relação, coexistência ou conexão necessária e existência real. Por isso, as qualidades conhecidas intuitivamente, imediatamente, são sempre secundárias, na medida em que são derivadas, ou seja, não pertencem às coisas mesmas, mas às operações da mente. Como, no entanto, há percepções que não se referem a nenhum órgão sensitivo em particular, embora somente sejam perceptíveis, segundo Locke, por meio dos objetos, como que os constituindo, se lhes deu o nome de "qualidades primárias". Kant mostrará, contudo, que mesmo o que percebemos já é previamente conformado pela mente de modo que nada do que se percebe pode ser legitimamente atribuído à coisa mesma, ou seja, que todo corpo é extenso em si mesmo, por exemplo. Diríamos, pois, que em Locke ainda persiste algo de realismo - decerto, não epistemológico, mas ontológico, pois a dependência a que é submetida a mente obriga à suposição de uma realidade exterior subsistente em si e por si mesma; a coisa em si é, com efeito, alguma coisa dotada, como tal, de determinações apreensíveis direta ou indiretamente pelos sentidos.

${ }^{9}$ A lei da causalidade, como é sabido, consiste naquilo a que Schopenhauer reduz todas as categorias do entendimento estabelecidas por Kant. Aqui, como em muitos lugares, Schopenhauer se exprime como se isto já fosse a tese de Kant, uma vez que Schopenhauer crê apenas sintetizar o que já dissera seu antecessor. Com efeito, não é, e o próprio Schopenhauer o declara nas diversas ocasiões em que critica a doutrina kantiana do entendimento.

${ }^{10}$ A esta altura é ainda bastante complexo explicar (e justificar) de modo tão coeso quanto preciso a identificação operada por Schopenhauer entre cérebro e intelecto (Intellekt), já pressuposta no uso anterior feito da palavra "cérebro", mas ainda não avançada nos capítulos correspondentes do primeiro tomo, mesmo porque pertence a sua teoria das sensações. Afinal, Schopenhauer não é um materialista; toda matéria, ainda que em sentido mais stricto, é representação, um objeto intelectual, como já foi visto. Isto, por sua vez, nos faz reconhecer que a identificação já era implícita desde o começo. Ordinariamente, em $O$ mundo como vontade e representação, "matéria" é empregado em sentido lato, correspondendo ainda a "causalidade" na medida em que abrange toda a gama dos objetos da intuição empírica. Do ponto de vista da representação, a realidade mais imediata é "meu próprio corpo". Como o intelecto é impalpável (razão pela qual tradicionalmente se o estimou como poder da alma), tratando-se de um conceito relativo ao "órgão" ou faculdade responsável pelo conhecimento, do ponto de vista de sua concretude intuitiva, desprezada a abstração tardia que o vincula à alma, o intelecto se manifesta como cérebro, ou seja, o cérebro consiste no fenômeno objetivo e material do órgão cognitivo central, ligando-se aos órgãos sensoriais periféricos por intermédio dos nervos. Cuidado é necessário, contudo, para que não se confunda o intelecto assim descrito com a inteligência de que se ocupará Schopenhauer ao discorrer sobre a possibilidade humana de vislumbrar o mundo como Vontade e, assim, entrever o em-si.

${ }^{11} \mathrm{Na}$ terminologia de Schopenhauer, vale dizer, "pensamento" tem um significado bastante desinflado, restrito à representação conceitual, que sempre deriva de intuições empíricas. O mundo intuitivo, que absolutamente nada contém de abstrato - razão pela qual seu conteúdo consiste no saldo obtido pela subtração de todo conteúdo conceitual -, consiste naquilo que é imediatamente informado pelos sentidos segundo as condições a priori da intuição que dão forma a esta
} 
Logo, os nervos dos órgãos sensoriais conferem aos [24] objetos fenomenais [erscheinenden Objekten] cor, som, sabor, odor, temperatura etc.; então o cérebro lhes confere extensão, forma, impenetrabilidade, mobilidade etc. ${ }^{12}$, em suma, o que é representável somente por meio de tempo, espaço e causalidade. Quão pequena é a parte dos sentidos na intuição, em contrapartida à do intelecto, também testemunha a comparação entre o aparelho nervoso para recepção das impressões e aquele para seu beneficiamento [Verarbeiten]; a massa dos nervos de todos os órgãos sensoriais é muito pequena comparada à do cérebro, mesmo nos animais, cujo cérebro, visto que propriamente não pensa, i.e. não abstrai, serve somente para que se produza a intuição, sendo esta perfeita [vollkommen] onde há uma massa [cerebral] considerável, portanto, nos mamíferos; isto mesmo depois de extraídos os cerebelos, cuja função é organizar a direção dos movimentos ${ }^{13}$.

Sobre a deficiência dos sentidos para a impressão das intuições intuitivas das coisas, como também sobre a fonte não-empírica das intuições de espaço e tempo, conservou-se, como confirmação das verdades kantianas, pela via negativa, uma convicção muito exemplar no excelente livro de Thomas Reid $^{14}$ : Inquiry into the human mind, first edition 1764, 6th edition 1810 [Investigação da mente

matéria e a constituem como tal no intelecto. O que mais tarde, conforme às operações da mente, se produz na consciência, como qualidades genéricas que constituem os conceitos, resulta de um processo de abstração (i.e. extração, ato de trazer para fora) de elementos comuns a uma pluralidade de dados empíricos. Destituídos da faculdade de abstrações e, portanto, de pensamento, os animais vivem encerrados na imediaticidade presente, uma vez que lhes escapa tudo que não seja estritamente particular e atual. Para Schopenhauer, os sentidos e as funções cerebrais operam em sinergia, de maneira que o mundo é representado segundo a constituição natural do aparato cognitivo, ficando mais claro agora em que sentido cérebro e intelecto são identificáveis. Sobre a proporcionalidade entre as faculdades e seus órgãos, ver exemplo a seguir.

12 Portanto, o que ainda Locke atribuía, na condição de qualidades primárias, à coisa em si, ou objeto dos sentidos, Schopenhauer, a partir de Kant, afirma como obra do entendimento.

${ }^{13}$ Algum cuidado é necessário, ao menos a esta altura da doutrina de Schopenhauer, na compreensão de seu exemplo. Schopenhauer, reconhecendo a força das ciências naturais em sua época - neste caso, a Biologia, que gozava de imensurável estima, como ainda hoje - e às quais dedicou estudos, faz uma explícita analogia, já aludida imediatamente antes, entre o poder das faculdades e a medida dos órgãos a elas vinculados. Trata-se de dizer que testemunhamos na anatomia a verdade de que os sentidos pouco contribuem para o conhecimento quando comparados à função do cérebro, mesmo mutilado, valendo isto para humanos e animais. Inclusive, é justamente por não possuírem cérebro que a plantas, diferentes dos animais, careceriam de entendimento e, portanto, de intuições propriamente ditas, assim como os animais carecem de pensamento. Trata-se, em suma, da tradicional questão acerca do que se sente de modo passivo e o que se conhece de modo ativo. O referido cuidado é para que se não interprete Schopenhauer como um naturalista do tipo que encontra, na anatomia, a explicação para o modo de ser do conhecimento; a anatomia fornece antes um testemunho, uma manifestação fenomenal de algo mais profundo, essencial, metafísico, de que as ciências naturais não podem dar conta: o fato de que a constituição das formas de vida seguem os graus de objetivação da Vontade, isto é, como a Vontade se fenomeniza na natureza, tema do livro II de $O$ mundo como vontade e representação. É porque a realidade se radica no intelecto e não nos sentidos (ou fora do corpo) que a massa cerebral é maior dos que a dos nervos sensoriais; é o cérebro que produz o mundo (como representação), não o sujeito, tampouco a Vontade. Uma teoria segundo a qual o cérebro aumenta por causa dos sentidos mais e mais refinados no contato com o ambiente externo (interacionismo) consiste na tomada do efeito pela causa; maior o cérebro, maior e mais complexo é o próprio mundo. Muito embora Schopenhauer admita que o mundo natural é absolutamente determinístico e que, portanto, o corpo sofre efeitos e causa tantos outros, a perspectiva do mundo como Vontade (se é que esta expressão pode ser tida como rigorosamente legítima, contra o que se poderá argumentar em momento propício) vem denunciar especificamente a deficiência de toda e qualquer explicação naturalista, visto que, já condicionada pelo entendimento, consiste em mera representação que nada diz da coisa em si.

${ }^{14}$ Thomas Reid (1710-1796), filósofo religioso escocês, contemporâneo de Hume, tendo fundado a Escola Escocesa do Senso Comum, recusava as consequências céticas do pensamento de seu conterrâneo. A obra referida por Schopenhauer ainda tinha acrescentado a seu título "sobre os Princípios do Senso Comum", e fora publicada no ano que Reid passou a ocupar a cadeira de Adam Smith na Universidade de Glasgow. 
humana, $1^{\mathrm{a}}$ ed. de $1764,6^{\mathrm{a}}$ ed. de 1810]. Este recoloca a doutrina de Locke de que a intuição seja um produto dos sentidos, demonstrando de modo sólido e perspicaz que nenhuma sensação tem a mínima semelhança com o mundo intuitivamente conhecido, especialmente que as cinco qualidades primárias de Locke (extensão, figura, solidez, movimento, número) não podem ser de modo algum fornecidas por nenhum dos sentidos ${ }^{15}$. Ele [Reid], a seguir, deixou a pergunta pela formação e origem da intuição totalmente insolúvel. Assim, apesar de desconhecer Kant por completo, ele fornece, por assim dizer, por regula falsi, uma sólida prova para a intelectualidade da intuição (exposta em primeiro lugar propriamente por mim, a partir da doutrina kantiana ${ }^{16}$ ) e para a descoberta de Kant da origem apriorística dos seus elementos fundamentais, o espaço, o tempo e a causalidade, do que primeiramente se deduzem aquelas propriedades primeiras lockeanas, sendo por seu intermédio que estas últimas facilmente se constroem. O livro de Thomas Reid é muito [25] instrutivo e digno de ser lido, dez vezes mais do que tudo de filosófico que foi escrito depois de Kant tomado em conjunto. Uma outra prova indireta para sua doutrina, embora pela via do erro, forneceram os filósofos sensualistas franceses, que, desde Condillac nas pegadas de Locke, se cansaram de efetivamente demonstrar que todas as nossas representações e pensamentos recaem sobre simples sensações (penser c'est sentir [pensar é sentir]), que eles denominam, segundo o processo de Locke, ideias simples, e por cujas associações e comparações simplesmente deve se construir todo o mundo objetivo em nossa cabeça. Estes senhores realmente têm des idées bien simples [ideias bem simples]: é divertido ver como eles, privados tanto da profundidade do filósofo alemão como da honestidade do inglês, viram para lá e para cá aquela matéria pobre da sensação e procuram torná-la importante para dela compor o fenômeno tão cheio de sentido do mundo-representação e do mundo-pensamento. Mas o homem que construíram deveria ser, falando

\footnotetext{
${ }^{15}$ É impreciso falar em uma doutrina lockeana da produção da intuição pelos sentidos, que são simples (e exclusivas) fontes do material da intuição, não esgotando suas possibilidades, como foi observado na nota 8 . Afinal, as operações mentais, a começar pela atenção, passando pela comparação das ideias, são o que efetivam qualquer conhecimento ou consciência do mundo externo e da própria interioridade. Não fica tão claro, até este momento, se Schopenhauer assim o interpreta, contudo. Parece acertado dizer que Locke distingue aquilo que é pertinente estritamente à mediação dos sentidos, as qualidades secundárias, que portanto variam segundo a constituição dos órgãos sensoriais, daquilo que é primordialmente pertinente à coisa percebida como condição mesma de sua perceptibilidade, denominado qualidades primárias. De fato, para Locke, a impressão de uma coisa extensa advém dos sentidos (visão, tato), já que a intuição, para ele, consiste na percepção de acordo ou desacordo entre ideias, mas, por sua vez, a percepção de algo como extenso consiste em uma atividade mental. De todo modo, o que está em jogo aqui, em primeiro lugar, é o problema da origem das qualidades primárias - se o objeto ou o sujeito -, e, em segundo lugar, o problema do potencial cético do empirismo, já aludido na nota 6. A propósito, a tese que consagrou Hume, a saber, que a ideia de conexão necessária consiste em uma crença, já é preconizada por Locke no capítulo XXVI do livro II de seu Ensaio, onde se lê: "para se ter a ideia de causa e efeito basta considerar qualquer ideia simples ou substância como começando a existir pela operação de alguma outra, sem saber o modo desta operação" (grifos nossos) este não-saber, que Locke atribuía a uma operação imediata da mente que intuitivamente percebe, graças à experiência, uma relação, Hume afirmará taxativamente ser uma crença oriunda do hábito.

${ }^{16}$ Aqui, como em inúmeras ocasiões, Schopenhauer, com razão e modéstia à parte, clama para si a originalidade de sua teoria do conhecimento sem nunca deixar omissa a sua filiação (sempre crítica) a Kant. Aliás, se a doutrina kantiana é a fonte da schopenhaueriana, sua originalidade decorre justamente da revisão radical da doutrina do entendimento - implicando, por conseguinte, a recusa de quase todo o resto -, que nada mais tem de predicativo. Poder-se-ia dizer que o entendimento, em Schopenhauer, é uma faculdade muda e mesmo incapaz de produzir uma consciência propriamente dita, sendo sua crítica fundamental a Kant a inserção ilegal de conceitos puros no entendimento.
} 
anatomicamente, um anencephalus [anencéfalo], um tête de crapaud ["cabeça-de-sapo"17], somente dotado de órgãos sensoriais, sem cérebro. Para citar como exemplo somente um par das melhores tentativas em inumeráveis desta espécie, nomeio Condorcet no início de seu livro Des progrès de l'esprit humain [Dos progressos do espírito humano] e Tourtual sobre a visão no segundo volume dos Scriptores ophthalmologici minores, edição Justus Radius (1828).

O sentimento [Gefühl] de deficiência de uma explicação simplesmente sensualista para a intuição manifesta-se igualmente, pouco antes da aparição da asserção pronunciada pela filosofia kantiana, naquela de que nós, excitados pela sensação, não temos apenas representações das coisas, mas as coisas mesmas imediatamente percebidas ${ }^{18}$, apesar de situadas fora de nós; sem dúvida isto é incompreensível. E isto não foi visto de modo mais ou menos idealista, mas declarado do ponto de vista realista habitual. O louvado Euler ${ }^{19}$ pesou bem e precisamente esta asserção em suas "Cartas a uma princesa alemã", v. 2, p. 68. "Eu penso então que as sensações (os sentidos) contêm ainda mais um pouco do que julgam os filósofos. Elas não são somente percepções vazias de determinadas impressões feitas no cérebro ${ }^{20}$; elas dão à alma [26] não só ideias das coisas; elas também lhe apresentam objetos reais [stellen ihr auch wirklich Gegenstände vor], que existem fora dela, embora não se possa compreender como isto propriamente se dá.” Esta opinião se explica pelo seguinte: apesar de a intuição nos proporcionar, como demonstrei suficientemente ${ }^{21}$, o emprego consciente ${ }^{22}$ a priori da lei da causalidade, neste caso, todavia, chega com a visão o ato do entendimento, por meio do qual, de modo algum com clara consciência, nós passamos do efeito à causa; daí não se separa a sensação da representação da matéria bruta, formada primeiramente pelo entendimento. Ainda menos pode vir à

\footnotetext{
17 Trata-se de uma denominação popular para anencefalia, fazendo referência ao aspecto da cabeça de recém-nascidos acometidos por esta má-formação fetal, que não implica, necessariamente, a ausência total de cérebro.

${ }^{18}$ Trata-se do mais radical realismo sensualista que, aliás, corresponde ao que pressupõe o senso comum mais rudimentar e acrítico, que despreza o contrassenso que há em se conceber uma percepção pura e sem mistura de algo que nos chega à consciência passando por uma série de órgãos e nervos. Os partidários desse modo de pensar não apenas supõem que os órgãos sensoriais sejam perfeitos e adequados a seus objetos, uma maravilha da natureza, como se rebelam contra toda forma de questionamento desta perfeição, atribuindo, ao contrário, aos sentimentos e à reflexão a deturpação e complexificação do que é em verdade simples e evidente por si mesmo. Não é à toa que esse modo de pensar consiste precisamente naquele que mais repele a crítica filosófica das supostas obviedades.

${ }^{19}$ Leonard Paul Euler (1707-1783) foi um importante matemático suíço de Basileia. As referidas cartas, escritas em São Petersbugo entre 1768 e 1772, foram publicadas em três volumes sob o título Lettres a une Princesse d'Allemagne sur quelques sujets de physique et de philosophie (Cartas a uma princesa da Alemanha sobre alguns assuntos de fisica e de filosofia).

${ }^{20}$ Eis a concepção lockeana, conforme exposto em notas acima, aqui criticada por Euler. Ou seja, as sensações que se imprimem no cérebro mediante a atenção, sendo então percebidas, tornando-se ideias na mente, por si sós e isoladamente, seriam vazias até que a intuição lhes conferisse sentido mediante suas operações comparativas.

${ }^{21}$ SG/PR e WWV I/MVR I.

${ }^{22}$ Note-se que se trata de uma consciência concreta, pré-reflexiva, que não se confunde com a compreensão ordinária, subjetiva e abstrata, de "consciência" como um estado mental como é a "consciência de si", das próprias operações, de se ter um "eu" etc. É uma consciência imediata dos objetos do entendimento oriundos da sensibilidade que representam, a própria matéria e conteúdo real dos conceitos. Tal imediaticidade - não que não haja meios, mas, sim, que não há intuições ou pensamentos mediadores - oculta o processo e, assim, faz crer que a sensação, a representação e a coisa são o mesmo. Nesse "vazio" o sensualista acredita encontrar sua prova.
} 
consciência uma diferença entre objeto e representação, que, aliás, não tem $\operatorname{lugar}^{23}$; mas nós tomamos todas as coisas mesmas como imediatamente verdadeiras, isto é, como situadas fora de nós; embora seja certo que somente a sensação pode ser imediata, esta se encontra na região abaixo de nossa pele ${ }^{24}$. Isto é assim explicável: o fora de nós é uma determinação [Bestimmung] exclusivamente espacial, o espaço mesmo é uma forma de nossa faculdade intuitiva, isto é, uma função de nosso cérebro; portanto, o fora de nós, para onde nós transferimos objetos, por motivo da sensação visual, jaz dentro de nossas próprias cabeças: pois aí está todo cenário ${ }^{25}$. Mais ou menos como nós vemos no teatro montanhas, floresta e mar, porém tudo permanece ali dentro da casa. Com isto se torna compreensível que nós intuamos de modo inteiramente imediato a coisa com a determinação fora de..., mas não uma representação nela mesma diferente de coisas situadas no exterior. Pois no espaço e, por conseguinte, também fora de nós estão somente as coisas enquanto as representamos: daí estas coisas que nós intuímos em tal medida imediatamente serem de fato exatamente o mesmo que nossas representações, não simples cópias suas, e, como tais, existirem [vorhanden] somente em nossa cabeça. Enfim, não contemplamos as coisas situadas no exterior, como diz Euler, imediatamente nelas mesmas; pelo contrário: as coisas contempladas como situadas fora de nós são somente nossas representações e por isso uma de nossas apreensões [Wahrgenommenes] imediatas. Todas as observações mais acertadas e justas nas palavras de Euler fornecem, portanto, uma nova confirmação da estética transcendental kantiana [27] e da minha teoria da intuição nela apoiada como, aliás, a do Idealismo. As suprarreferidas imediaticidade e inconsciência com que nós, pela intuição, fazemos o passo da sensação para sua causa deixa-se explicar por um processo análogo nas representações abstratas, ou pensamento. Na leitura e na escuta, nós só recebemos palavras, mas vamos diretamente destas para os conceitos denominados por meio delas, isto é, como se nós recebêssemos imediatamente os conceitos: pois não nos tornamos nem um

\footnotetext{
${ }^{23}$ Conforme exposto no início do capítulo - questão retomada logo a seguir - e comentado nas notas, a identidade entre objeto e representação proposta por Schopenhauer se opõe ao realismo na medida em que, já vimos, todo objeto é intelectual, e isto graças à exclusão da coisa em si como termo da relação identitária. Onde o senso comum reconhece a evidência de uma realidade exterior, Schopenhauer aponta a prova de que o mundo conhecido só existe como representação, distanciando-se de uma compreensão ingênua da natureza de nossas percepções.

${ }^{24} \mathrm{Ou}$ seja, no rigor do termo, nenhuma representação pode ser imediata, como diz o termo "Vorstellung”, cujo prefixo já indica um meio, um espaço entre uma coisa e outra, um vão entre sujeito e objeto em relação, sendo a mediação feita aqui pelos órgãos nervosos e condições intelectuais da experiência. Desse modo, Schopenhauer reconhece a imediaticidade com que os sentidos seriam estimulados, mas, ao contrário de significar uma evidência da exterioridade do objeto, isto se realiza mediante a afetação sofrida pela superfície do corpo e isto, por sua vez, graças ao que se encontra imediatamente debaixo dela, a saber, a periferia de nosso sistema nervoso. Do ponto de vista do sujeito, contudo, trata-se de uma apreensão imediata e inconsciente, como tradicionalmente se compreende intuição na Filosofia.

${ }^{25}$ V. acima, n. 3. A metáfora do mundo como teatro, da realidade como encenação, é muito cara a Schopenhauer, que aparentemente se inspira na repetidamente aludida tragédia de Calderón de La Barca La vida es sueño. Embora o verbo alemão "stellen" permita a acepção de "fingir", como quando se diz "ich stelle mich", a conotação, a nosso favor, é bem mais forte em português, onde "representar", na linguagem comum, logo adquire a rica acepção de "desempenhar um papel", "atuar como", seja no sentido de "agir de modo a ser tomado por outro", um personagem em verdade fictício, ou seja, "fazer parecer", como no sentido de "agir em nome de outro", ou seja, em lugar de outro, como um membro de um grupo que se manifesta em seu lugar ou um mensageiro que fala em nome de outro. Eis em que concretamente consiste o mundo das representações.
} 
pouco conscientes dos passos em sua direção. Por isso, às vezes, não sabemos em que idioma acaso lemos ontem, coisa de que nos recordamos no que concerne ao dia de hoje. Contudo, torna-se perceptível que semelhante passo tem lugar todas as vezes quando alguma vez ele falha, isto é, quando nós, na recreação [Zerstreuung], lemos descuidadamente [gedankenlos] e então nos damos conta de que nós havíamos recebido cada palavra, mas nenhum conceito. Somente quando nós omitimos conceitos abstratos para as figuras da fantasia ${ }^{26}$ nos tornamos conscientes da conversão.

Aliás, a inconsciência da percepção empírica com que se dá o passo da sensação para suas causas só se encontra propriamente na intuição em sentido estrito, a saber, no lugar da visão; entretanto, ele se dá com maior ou menor clareza de consciência em todas as outras percepções sensoriais, pois que, na apreensão pelos quatro sentidos mais grosseiros, sua realidade se deixa constatar, de fato, efetivamente. ${ }^{27}$ Apalpamos no escuro uma coisa, por tanto tempo e em todos os lados, até que nós possamos construir, a partir seus diferentes efeitos sobre as mãos, a causa dos mesmos como figura determinada. Além disso, quando algo é escorregadio ao tato, nós às vezes procuramos refletir se temos alguma gordura ou óleo nas mãos; normalmente, também, se temos as mãos muito quentes quando o contato é frio. Às vezes, duvidamos em um som se foi só interior ou efetivamente uma afecção dos ouvidos oriunda de fora; em seguida, se ressoa próximo e fraco ou distante e forte; depois, de que direção veio; finalmente, se foi a voz de homens, de animais ou de instrumentos: assim, no efeito dado, nós investigamos em direção à causa. No odor e no gosto é [28] cotidiana a incerteza sobre a natureza da causa objetiva do efeito sentido: [embora] tão inequivocamente separados cheguem a nós. Para que o passo do efeito para a causa aconteça de modo inteiramente inconsciente na visão, e desta maneira se produza a aparência, como esta espécie de percepção foi totalmente imediata, existente só na sensação sem atuação do entendimento, isto tem sua razão [Grund] parcialmente na elevada conveniência ${ }^{28}$

\footnotetext{
26 "Figuras da fantasia", neste caso, são as palavras que, produzidas posteriormente às ideias gerais, são utilizadas para a denominação dos conceitos (v. cap. 6). Aqui a tradução francesa de Burdeau comete um grave deslize ao dizer: "É somente quando nós passamos de conceitos abstratos a signos figurados", isto é, palavras escritas, "que temos consciência da transposição". Evidentemente, esta versão desconsidera por completo e mesmo inverte o que Schopenhauer acabara de dizer em seu exemplo, pelo qual o autor afirma: apenas se tem consciência do processo quando ele não acontece, quando o passo não tem lugar, sem mencionar que o próprio "caminho" é o oposto, a saber, são as palavras escritas a ir ao encontro dos conceitos; quando não damos atenção ao que está escrito, a informação oriunda da visão como que encontra seu caminho natural bloqueado, de modo que seu significado passa em branco.

${ }^{27}$ Naturalmente, esta "realidade" é intuitiva, referindo-se à ordem representacional. A afirmação de Schopenhauer é simples de se compreender: enquanto as causas daquilo que vemos parecem evidentes, irrefletidas, o mesmo não se dá com os demais sentidos a não ser quando nossos olhos nos esclarecem, seja pela visão atual, seja pela lembrança de algo já visto disto o próprio autor dá exemplos a seguir. Aliás, cabe observar a relativa fidelidade de Schopenhauer à tradição que compreende a intuição como espécie de visão, bem como a primazia deste sentido sobre os demais, sobretudo em Platão, que chegou a derivar daí seu conceito de "Ideia" como objeto da contemplação, ou theoria, a visão do suprassensível.

${ }^{28}$ Optou-se por "conveniência" em vez de "perfeição" não por uma simples questão de elegância, tanto menos por se tratar de uma tradução rigorosamente literal. "Convir", do latim "convenire", isto é, "vir ao encontro em sua totalidade" (Voll-kommen), "estar de acordo, adaptado", indica com grande precisão o que pretende dizer Schopenhauer, a saber, a conformidade e a proporção de faculdades intelectuais e órgãos sensoriais. O termo "perfeição", que indica algo acabado, pronto, definitivo, a que nada se pode acrescentar, dá margem a alguns vícios de leitura pelo quais se poderia inadvertidamente vincular Schopenhauer à tradicional doutrina da suma racionalidade da natureza em si como obra de um ser onisciente, bom e todo-poderoso. Sua doutrina, ao contrário, nos ensina que a racionalidade da natureza pertence a nosso
} 
[Vollkommenheit] dos órgãos, parcialmente no tipo de efeito exclusivamente retilíneo da luz. Esta última [a visão] já é capaz de guiar a impressão mesma ao lugar da causa e então o olho tem aberta a capacidade de perceber, com exatidão e numa só visada, todas as nuances da luz, sombra, cor e contorno, bem como os dados segundo os quais o entendimento avalia a distância; deste modo acontece a atuação do entendimento sobre as impressões desse sentido, com tanta rapidez e segurança que muito pouco se permite chegar à consciência, como o soletrar durante leitura; por meio disso, portanto, a aparência se produz como se a sensação mesma já desse os objetos imediatamente. Contudo, a operação do entendimento, vigente no reconhecimento da causa pelo efeito, é mais importante precisamente na visão ${ }^{29}$ : em virtude de tornar simples a percepção dupla intuída com dois olhos; em virtude de tornar reordenada a impressão, que se converte de ponta-cabeça sobre a retina em decorrência do cruzamento dos raios na pupila, graças à perseguição da causa, que encontra na mesma direção o caminho de volta, ou, como se diz, nós vemos a coisa em pé, apesar de sua imagem no olho estar invertida; em virtude de aquela atuação do entendimento, afinal, tornar grandeza e distância avaliadas em nossa intuição imediata a partir de cinco dados diferentes, que Thomas Reid descreveu muito bem e claramente. Eu expliquei tudo isto, bem como as demonstrações que provam irrefutavelmente a intelectualidade da intuição, já em 1816 em meu ensaio "Sobre a visão e as cores" (segunda edição de 1854), com importantes acréscimos na adaptação corrigida para o latim quinze anos depois, que, sob o título Theoria colorum physiologica eademque primaria [Teoria fisiológica fundamental das cores], se encontra editada por Justus Radius, em 1830, no terceiro volume dos Scriptores [29] ophthalmologici minores, profunda e minuciosamente detalhada, todavia, na segunda edição de minha dissertação "Sobre o princípio de razão" ${ }^{\prime 30}, \S 21$. Para ali, enfim, eu remeto [o leitor] sobre este importante assunto a fim de não encher ainda mais o presente esclarecimento.

Entretanto, uma observação conclusiva na estética pode encontrar aqui seu lugar. Em virtude da demonstrada intelectualidade da intuição, a vista de uma coisa bela, p. ex. um belo panorama, é de fato

modo de representação e por ele se produz, sendo assim dada a priori graças ao intelecto. Por sua vez, "perfeição" significaria apenas o caráter inequívoco da intuição, o que não é o caso no presente momento em que o autor refere-se apenas ao sentido da visão; de todo modo, com esta ressalva, admite a primazia da visão graças a esta Vollkommenheit. A relativa perfeição da visão - se acaso se permite falar em "perfeição relativa" - diz respeito ao grau de imediaticidade das intuições calcadas no visível relativamente ao palatável, ao tangível, ao audível. A gradação é confirmada pela palavra "elevada", inútil se se tratasse de uma perfeição propriamente dita, mas muito adequada em se tratando de uma conveniência privilegiada. Em ocorrência anterior, o vocábulo "vollkommen" foi traduzido como "perfeição", uma vez que ali se tratava, especialmente, da perfeição da intuição nos mamíferos, pois estes, em toda a natureza, são os únicos capazes de intuições propriamente ditas tal como Schopenhauer as compreende. Desse modo, podemos adotar "perfeição" no que se refere ao entendimento, com ressalvas de que isto não implica realismo epistemológico, mas sugere-se que se dê preferência a "conveniência" quando se trata da relação entre os objetos e os órgãos pelos quais se produzem no cérebro, ou seja, por via de nossa sensibilidade e nosso entendimento.

${ }^{29}$ Os exemplos seguintes são de notável importância no sentido de esclarecer, a despeito de sua imediaticidade, em que contribuem as faculdades estritamente intelectuais/cerebrais (ativas) para os órgãos da visão (passivos), salientando-se ainda mais nossa inconsciência acerca do processo.

${ }^{30}$ Trata-se da versão revista e ampliada, de 1847, da dissertação Sobre a quádrupla raiz do princípio de razão suficiente, primeira grande obra de Schopenhauer, publicada originalmente em 1813. Aqui, a referência do autor abrevia o título. 
um fenômeno cerebral. A pureza e a perfeição do mesmo, pois, não dependem somente do objeto, mas também da constituição do cérebro, a saber, de sua forma e seu tamanho, da delicadeza de sua textura e do fomento de sua atividade por meio da energia dos pulsos das veias cerebrais ${ }^{31}$. Por conseguinte, a imagem do mesmo panorama em diferentes cabeças, mesmo que os olhos tenham igual acuidade, fica determinada tão diferentemente como a primeira e a última impressões de um clichê de cobre muito usado. Nisto se baseia a grande diferença da capacidade de fruir a bela natureza e, por conseguinte, também de imitá-la, isto é, de produzir os mesmos fenômenos cerebrais por meio de uma causa completamente heterogênea, a saber, as manchas de cor sobre uma tela.

Aliás, a aparente imediaticidade baseada na total intelectualidade da intuição, em virtude de que nós, como diz Euler, apreendemos a coisa mesma e como situada fora de nós, é análoga ao modo como nós sentimos as partes de nossos próprios corpos, sobretudo quando elas doem, sendo a maioria dos casos em que logo as sentimos ${ }^{32}$. Como cremos perceber a coisa imediatamente ali onde ela está, enquanto isto efetivamente acontece no cérebro, assim também nós sentimos a dor de um membro nele mesmo, enquanto esta do mesmo modo se torna sentida no cérebro, para onde a conduz o nervo das partes afetadas. Por isso, somente são sentidas as afecções de tais partes, cujos nervos vão para o cérebro, mas não daquelas cujos nervos fazem parte do sistema ganglionar; a não ser que uma afecção excessivamente forte insista em voltar até o cérebro, onde geralmente ela só se dá a conhecer como apática indisposição e sempre sem [30] exata determinação de sua localização. Por isso, também, não são sentidos os ferimentos de um membro cujo tronco nervoso é cortado ou interrompido. Por isso,

\footnotetext{
${ }^{31}$ Pressupostas as observações feitas na nota 13, reiteramos que este trecho não significa a adesão absoluta de Schopenhauer à biometria tão em voga no século XIX que, hoje, é tão corriqueira. Os médicos nos mensuram e computadores avaliam nossas proporções deste o útero materno. Entusiasta da Biologia como testemunha da correção de sua metafísica, Schopenhauer encontra na conformação fisiológica a medida da capacidade representacional, razão pela qual ele tantas vezes recorre aos achados daquela ciência em seus exemplos tirados do mundo natural. A boa atividade cerebral dependerá de sua boa constituição fisiológica; esta, porém, dependerá da perfeição com que a Vontade se manifesta no mundo dos fenômenos como corpo. Isto à parte, desde Foucault, em especial, as consequências da biometria, levada aos mais bizarros excessos como pelos nazistas, para se citar um caso paradigmático e do conhecimento geral -, têm sido objeto de duras críticas nas Ciências Humanas em geral, especialmente no ramo das Ciências Sociais em seu embate contra o naturalismo. Por polêmica que seja a perspectiva de Schopenhauer, que parece indicar (e de fato indica) uma proporção direta entre inteligência e constituição fisiológica - de que, mais adiante, no capítulo 6, teremos exemplo muito mais polêmico! -, deve-se levar em conta, antes de tudo, o sentido geral e mais imediato de suas asserções, sob pena de obliteração de sua doutrina: estabelecer a primazia do intelecto/cérebro sobre as sensações/sentidos no que concerne ao modo como o mundo se dá para nós, não como algo exterior visto, mas interior intuído, não como algo que está fora e chega a nós, mas que está em nós como existente fora. Em seguida, o autor já alude à sua doutrina do gênio artístico, tematizada no livro III de $O$ mundo como vontade e representação. Trata-se, neste último caso, de atingir pela inteligência uma representação universal, a saber, a Ideia.

${ }^{32}$ V. WWV I/MVR I, § 6. Importante aqui é observar a alusão à famosa tese de Schopenhauer acerca do corpo como objeto imediato da intuição. Desde já fica claro que, ao percebemos nosso próprio corpo como algo distinto de nossa mente, conscientemente, o percebemos como representação, ou seja, trata-se de um objeto intelectual. O corpo que conhecemos, enquanto conhecido reflexivamente por um sujeito, é mediato. Por isso mesmo a dor, que está em nosso cérebro, é sentida como situada em alguma outra parte do corpo e imediatamente percebida. $\mathrm{O}$ caráter mediato de nosso conhecimento consciente do objeto imediato será tema de capítulo posterior. Além disto, a afirmação veraz de que nós tomamos consciência das partes de nosso próprio corpo quando elas doem ou causam incômodo não deixa de ser uma contribuição para a tese schopenhaueriana acerca da positividade da dor, bem como do prazer como simples meio para suprimi-la, ou seja, do caráter negativo deste último.
} 
enfim, quem perdeu um membro, às vezes, ainda sente dor nele, porque os nervos que vão até o cérebro ainda existem. - Portanto, em ambos os fenômenos aqui comparados, o que se dá no cérebro é apreendido como exterior a ele: na intuição, [o cérebro] estica o seu tentáculo até o mundo exterior pela mediação do entendimento; na sensação dos membros, pela mediação dos nervos.

\section{[67] CAPÍTULO 6}

\section{PARA A DOUTRINA DO CONHECIMENTO ABSTRATO, OU RACIONAL}

A impressão exterior sobre os sentidos, junto à disposição [Stimmung] que se produz sozinha e por si mesma em nós, desaparece com a presença das coisas ${ }^{33}$. Portanto, elas não podem constituir a experiência propriamente dita, cuja lição para o porvir deve conduzir nossa ação. A imagem dessa impressão, aquela que a fantasia guarda, já é imediatamente mais fraca do que a impressão, a cada dia se enfraquece mais e se apaga por completo com o tempo ${ }^{34}$. Nem o desaparecimento instantâneo das impressões nem o desaparecimento sucessivo das imagens a elas submetidas estão livres da força do tempo; consequentemente, apenas uma coisa está: o conceito $^{35}$. Assim, nele deve estar fixada a experiência instrutiva e só ele se presta a assegurar a condução de nossos passos na vida. Eis por que diz Sêneca com retidão: "Si vis tibi omnia subjicere, te subjice rationi" [Se queres tudo submeter a ti, te submetas à razão] (Epístola 37). E acrescento, para cobrir [überlegen] os outros na vida efetiva, esteja coberto [überlegt], isto é, proceda segundo conceitos, que é a condição indispensável ${ }^{36}$. Um tão

\footnotetext{
${ }^{33}$ Como se constatará ao longo do capítulo, Schopenhauer combate aqui o sensualismo que defendia algo como um "conhecimento/pensamento dos sentidos", como se estes, sozinhos, fossem capazes de conhecer. Como órgãos passivos, aquilo que transmitem ao cérebro não permanece neles, mas se perde quando cessa a afetação imediata pelo objeto. Sem a participação de faculdades estritamente intelectuais, a sensação não pode produzir memória nem experiência, cada sensação é única e instantânea, o mesmo se dando com qualquer sentimento interno por ela produzido em nós. Desse modo, Schopenhauer refutará a tese que defende intuições sensíveis, bem como o empirismo estrito. Como foi visto no capítulo 2 , toda intuição é intelectual. Agora, Schopenhauer afirmará que todo pensamento é abstrato e, portanto, dependente de conceitos.

${ }^{34}$ Também a faculdade da imaginação não basta à retenção definitiva de uma impressão sensível. A imagem mental produzida já é, em sua origem, empalidecida em relação à impressão que reflete. Portanto, uma ideia, em Schopenhauer, não pode ser simplesmente a imagem mental produzida mediante a excitação dos sentidos.

${ }^{35}$ Assim como tempo, espaço e causalidade constituem o conhecimento intuitivo, o conceito é o elemento fundamental do conhecimento abstrato. Os dados sensíveis, enquanto tais, produzem-se como que mecanicamente segundo a constituição dos organismos, determinando a natureza temporal e impermanente dos produtos da imaginação que deles decorrem. Resultantes de uma atividade intelectual, os conceitos conservam sua independência com relação ao tempo, embora permaneçam como meras representações secundárias; dependem das intuições, representações primárias, mas pertencem à intelectualidade.

${ }^{36}$ Se apenas o conceito não sofre com a ação do tempo, devendo nele se fixar a experiência e, portanto, nele se baseiam nossas ações, uma livre tradução do jogo semântico utilizado por Schopenhauer diria: colocar-se sobre os outros determinando-lhes o agir exige que se esteja colocado sob conceitos, ou seja, submetido à reflexão, ao pensamento. Uma vez que o verbo alemão "überlegen" significa tanto "colocar-se acima de" quanto "refletir", "pensar em”, a tradução pelo verbo "cobrir" assume duas conotações, a saber: "agir em lugar de alguém" e "abrigar-se sob algo". Interessante observar que, se
} 
importante utensílio da inteligência, como é o conceito, não pode evidentemente ser idêntico à palavra, este simples som que, como a impressão dos sentidos na presença ou como o fantasma da audição, emudece com o tempo. Por sua vez, o conceito é uma representação cuja clara consciência e cuja conservação estão ligadas à palavra: eis por que os gregos primeiramente chamaram por um nome “palavra”, "conceito", "proporção", "pensamento" e "razão": ó $\lambda o ́ \gamma o \varsigma^{37}$. Contudo, o conceito é tão completamente diferente das palavras a que está ligado quanto das intuições de que se forma. Ele é de uma natureza totalmente distinta dessas impressões dos sentidos. Porém, ele pode agregar dentro e em torno de si todos os resultados da intuição, bem como restituí-los depois do mais longo período, inalterados e não diminuídos: daí primeiramente se produz a experiência ${ }^{38}$. A intuição, ainda que junto às sensações, não conserva o conceito, mas seu essencial [Wesentliches, Essentielles] em todo aspecto [Gestalt] variante, quando substitutos o satisfazem. Assim, [68] as flores não se deixam conservar, mas sim seu óleo etéreo, sua essência, com mesmo odor e mesmas forças ${ }^{39}$. O agir que tivera corretos

em Sêneca, a máxima remete à sujeição do poder à natureza como signo de sabedoria, bem como ao domínio-de-si, em Schopenhauer isto adquire um tom contemporâneo, qual seja, relativo ao caráter dominador da racionalidade moderna, à nova concepção, formulada por Bacon, de que "saber é poder". O poder não mais busca legitimidade na sabedoria; ele se utiliza do saber como instrumento para sua própria afirmação. O caráter instrumental da racionalidade é evidenciado logo a seguir.

${ }^{37}$ Embora seu caráter intelectual garanta ao conceito a permanência de que os sons são destituídos, sua fixação na inteligência depende da palavra na medida em que, por meio desta, não enquanto objeto sensível, mas sim enquanto signo racionalmente determinado, torna-se possível memorizá-lo. Com isto Schopenhauer indica uma breve teoria dos signos linguísticos pela qual o conceito abstrato pode se ligar a um dado intuitivo independente de possuir ou não conteúdo empírico. A palavra lembrada é um objeto intelectual vinculado ao conceito, fixável graças a isto, não um fugaz objeto dos sentidos. Reconhecendo esse vínculo, segundo Schopenhauer, os gregos não faziam distinção ao dizerem "logos", que, em verdade, não dizia tanto respeito à fala quanto a seu sentido, não sendo por outro motivo que uma fala sem significado, ainda que pronunciada e reconhecida, era considerada "ilógica", "irracional". Podemos unir as palavras de tal modo a proferirmos "Sócrates não é Sócrates", mas, com isso, nada é dito, pela simples razão de que tais palavras, meramente faladas, unidas desse modo, não remetem a conceito algum, tampouco a algo real. O que lemos até aqui consiste em uma nova abordagem do que é dito em meio à exposição do $\S 8$ do primeiro tomo, onde o foco incide sobre a diferença entre humanos e animais estes últimos, desprovidos de razão e, portanto, de conceitos, viveriam limitados ao presente. O que se segue aprofundará questões mencionadas apenas de passagem naquele lugar, bem como no $\S 9$, onde se concede espaço privilegiado a princípios de uma lógica geral dos conceitos e juízos.

${ }^{38}$ Schopenhauer aqui lança uma tese audaciosa: não basta a memória para que se derive, mesmo no homem, a experiência, como Aristóteles chegara a afirmar na Metafísica (980 b 28-29); ainda é necessário o conceito. Considerada a fugacidade dos dados sensíveis e das imagens que produzem, sua fixação na memória depende da vinculação a conceitos, os quais, por sua vez, se fixam graças às palavras. Isto parece significar que o ato de nomear e definir se encontra nas bases de toda experiência propriamente dita, ou seja, capaz de constituir efetivo conhecimento sobre o que quer que seja. Portanto, a mera repetição de impressões não é capaz de gerar conhecimento, pois, para isso, as diferentes impressões singulares devem ser reunidas sob a unidade de um conceito. Do mesmo modo, as palavras não são apenas auxiliares da memória como pensaram outros filósofos, mas sua condição. Conceitos ou ideias gerais não o são por terem sido extraídos de vários objetos (cf. WWV I/MVR I, § 9), não devendo ser explicados pelas relações de "semelhança de impressões" ou "concordância de ideias", que são antes efeitos do que causas da representação abstrata - nisto consistiria novo equívoco do sensualismo empirista. Em suma, é graças ao modo de representação da razão que as intuições não se perdem no fluxo temporal, sem o que uma simples faculdade da memória se tornaria ineficaz a longo prazo; isto porque, como vimos anteriormente, enquanto consciência imediata e não discursiva, a intuição não há de bastar à reflexão, repetição e conservação do que é experimentado em todas as suas determinações singulares.

39 À intuição pertence apenas a matéria-prima do conceito, a essência, ou seja, o que se dá como é. O que, no entanto, se há de conservar, neste caso, não é o que caracteriza uma dada flor singular, mas o que caracteriza suas similares, donde conceito e nome comuns a todas. Uma determinada flor está sob o mesmo conceito e recebe o mesmo nome de todas as suas semelhantes, muito embora, segundo Schopenhauer, esta seja uma qualidade acidental, não essencial aos conceitos (cf. WWV I/MVR I, § 9). 
conceitos por orientação geral, no resultado, vem encontrar-se com a efetividade planejada ${ }^{40}$. - Pode-se calcular o valor inestimável do conceito, e por conseguinte da razão, quando o olhar se lança sobre a quantidade e a diferença infinitas de coisas e situações existentes após e ao lado uma da outra e se reflete que, apesar disto, fala e escrita (os signos do conceito) são capazes de nos trazer notícia exata de cada coisa e cada relação, de quando e onde se deram; porque relativamente poucos conceitos apreendem [befassen] e representam [vertreten] justamente uma infinidade de coisas e situações. $-\mathrm{Na}$ reflexão propriamente dita, a abstração [Abstraktion] é um atirar ao solo bagagens inúteis em prol do mais fácil manejo para cá e para lá dos conhecimentos comparativos e em formação. Deixa-se de lado com isso o muito de inessencial [Unwesentliche $]^{41}$ que há no caminho das coisas reais, que somente gera confusões, e opera-se com as poucas, mas essenciais, determinações [Bestimmungen] pensadas in abstracto. Mas justamente porque os conceitos gerais [Allgemeinbegriffe] somente se formam por abstração [Wegdenken] e omissão de determinações existentes, e portanto, quanto mais gerais, mais vazios, o uso de tal procedimento se limita ao beneficiamento ${ }^{42}$ de nossos conhecimentos já adquiridos, ao qual também pertence a conclusão a partir das premissas neles contidas ${ }^{43}$. Novas compreensões fundamentais, pelo contrário, somente são tiradas do intuitivo, o conhecimento cheio e rico, com ajuda

\footnotetext{
${ }^{40}$ Considerando que se trata aqui de uma racionalidade instrumentalizada, portanto, do princípio do agir de fato em vista de interesses, Schopenhauer não está discutindo a ação moral, mas pragmática. Neste restrito âmbito - em verdade, o âmbito das ações cotidianas -, pautar-se em conceitos apropriadamente concebidos contribui para o efetivo sucesso de nossos planos. Trata-se da ação baseada no conhecimento empírico - indicada já no início do capítulo, que considera o mundo como representação, não como vontade -, do modo comum de agir. Como é sabido, a ação moral, segundo Schopenhauer, se funda em algo muito distinto, nada abstrato, a saber, a compaixão. Desse modo, o que é dito no presente capítulo não suprime, nem substitui, nem entra em conflito com o que Schopenhauer diz acerca da ação justa, moral, pois se trata de uma perspectiva completamente distinta. Aqui, Schopenhauer aborda a utilidade e mesmo a necessidade do conceito no mundo das ações humano, a que ele denomina "mundo prático" sem evocar a noção kantiana de "razão (pura) prática", que ele, aliás, recusa. ${ }^{41}$ A tradução de "Unwesentliche" pelo neologismo "inessencial" visa reforçar o papel fundamental da abstração na constituição do conceito, a saber, preservar da intuição tão somente o geral, o essencial, o comum, o que é relevante para o conceito, independente da possibilidade de esta generalidade, essencialidade, abarcar uma multiplicidade de indivíduos. A tradução por "insignificante" não comportaria suficientemente o sentido que se pretende transmitir, até porque "insignificante", derivadamente, adquire a acepção "de pouco ou nada digno de nota". Em verdade, são justamente estas insignificâncias que distinguem cada ente como singular, único, instantâneo e irrepetível, de modo que tal tradução poderia incorrer no erro de exprimir o contrário do que defende Schopenhauer. Desprezando-as, o conceito se afasta, na mesma proporção, da concretude imediata e real da intuição, podendo justamente por isso "funcionar" como instrumento de planificação, previsão e classificação, reduzindo cada coisa e situação a uma classe genérica. Mais acima, quando Schopenhauer pusera lado a lado as palavras "Wesentliches" e "Essentielles" também se poderia ter optado por traduzir "seu [conteúdo] significativo, essencial”, mas ali, além de soar redundante, parecia prematuro indicar o sentido pretendido com "significativo", bem como forçaria em demasiado a tradução. Ademais, comumente se testemunha a preferência de Schopenhauer por termos latinizados, tais como "Intellekt", "Abstraktion", de maneira a considerarmos legítima a tradução por uma única palavra, "essencial”, reconhecendo aí mera indicação de correspondência.

${ }^{42}$ V. nota 7 , acima.

${ }^{43}$ Sendo assim, conceitos, relativamente pobres e vazios por natureza, nada acrescentam ao nosso conhecimento; são apenas úteis. A partir do que conhecemos, podemos proceder a um refinamento, como quando depuramos um conceito no sentido de garantir ou estender sua universalidade. Do mesmo modo, no silogismo, evidenciamos um conhecimento inerente a premissas admitidas em conjunto, as quais, por sua vez, explicitam sob a forma de juízos o que já diz o conceito geral a que se referem - por exemplo, no conceito de "homem" já está incluída sua mortalidade, assim como já é inerente ao conceito de "Sócrates" a qualidade de ser homem, concluindo-se, a partir dos dois simples conceitos que Sócrates é mortal. Ou seja, juízos não geram conhecimento; apenas o exprimem. Tal perspectiva, tão aparentada ao nominalismo, parece contrariar a doutrina kantiana sobre o valor dos juízos sintéticos.
} 
da razão [Urtheilskraft]. - Porque, além disso, o conteúdo e a extensão do conceito estão em relação inversa, tanto mais há [de essencial] sob um conceito, tanto menos [de particular] é nele pensado; assim os conceitos formam um efeito-degrau, uma hierarquia, do mais específico ao mais geral, de cuja extremidade inferior se aproxima o realismo escolástico e, na superior, o nominalismo quase com justiça se conserva ${ }^{44}$. Porque o conceito mais específico já é quase o indivíduo, portanto quase real; e o conceito mais geral, p. ex., o ser (isto é, o infinitivo da cópula), quase nada é além de uma palavra. Eis por que sistemas filosóficos que se detêm em tais conceitos muito gerais sem descer para o real, de fato, são quase só papo-furado [Wortkram $]^{45}$. [69] Pois toda abstração [Abstraktion] só ocorre aí no abstrair $[\text { Wegdenken }]^{46}$; neste caso, quanto mais longe se prossegue, tanto menos sobra. Quando leio filosofemas modernos, que avançam muito apenas em abstrações, não obstante toda atenção, em pouco tempo eu quase nada mais posso pensar; porque mal alcanço alguma matéria para o pensamento, apenas com cascas vazias devo operar, o que dá uma sensação semelhante à produzida na tentativa de lançar um corpo muito leve: a força está aí, e também o esforço; mas falta ao objeto poder recebê-lo para se produzir o outro momento do movimento. Quem quiser experimentar isto, leia os escritos de um schellingiano e, melhor ainda, de um hegeliano. - Conceitos simples deveriam ser propriamente

\footnotetext{
${ }^{44}$ Nesta comparação, Schopenhauer relaciona os níveis extremos da "hierarquia dos conceitos" às escolas que profundamente se opunham no período medieval. De um lado, aqueles que defendiam a realidade do conteúdo de conceitos puramente inteligíveis, tais como "o maior", "o melhor", "bem supremo", "perfeição", "Deus", "ser" etc., perspectiva adotada mesmo por críticos racionalistas da escolástica como Descartes. Ao realismo racionalista e seu otimismo epistemológico Schopenhauer dirigirá severas críticas em toda sua obra. No outro extremo, temos a longa tradição nominalista britânica radicada no pensamento de Ockham, por cuja famosa "navalha" pretendia desinflar os conceitos do que fosse meramente inteligível afirmando que o conteúdo dos mesmos advém da experiência. Da perspectiva nominalista as doutrinas da abstração tiram sua força maior, tendendo ao ceticismo, como ocorre em Hume. Com ressalvas, algumas das quais já indicadas, Schopenhauer se mostra mais simpático a este ponto de vista. Colocá-lo no nível superior não significa uma "aprovação" irrestrita, mas dizer que os conceitos, conforme pensados pelos nominalistas, têm maior conteúdo intuitivo, enquanto aqueles pensados pelos realistas são vazios na proporção de sua universalidade. Desse modo, observamos a confusão expressa na clássica tradução francesa de Burdeau, que encerra o trecho dizendo que "o realismo escolástico e o nominalismo não estão longe de ter ambos razão". Afinal de contas, embora haja conceitos constituídos de uma forma e de outra, o que está em questão é quanto se pode atribuir de realidade a seus conteúdos, no que Schopenhauer não assume uma posição relativista. O exemplo a seguir confirma nossa posição. É também digno de se observar que, aqui, a hierarquia sugerida por Schopenhauer evoca a quantidade de conteúdo de um conceito, enquanto que, no $\$ 9$ do primeiro tomo, a metáfora utilizada diz o inverso, uma vez que, ali, vincula o máximo de conteúdo à concretude da intuição e, portanto, aos andares mais próximos do solo firme, ao passo que o mínimo de conteúdo remete àqueles mais próximos das nuvens, mais descolados da realidade. Esta metáfora é aludida em seguida.

${ }^{45} \mathrm{O}$ termo "Wortkram", difícil de traduzir diretamente, indica que se trata de palavras de ínfimo significado, desprezíveis. A opção por "papo-furado" tem em vista a avaliação profundamente depreciativa de Schopenhauer em relação aos sistemas filosóficos, sobretudo a ele contemporâneos, que giram em torno de conceitos tão vazios como "absoluto" ou "espírito". Logo adiante se seguirá uma crítica dessa "moderna filosofia". A propósito, a palavra "Krämergeist", literalmente "espírito de dono de mercearia", se refere a pessoas que apenas pensam em tirar vantagem de tudo, o que se aplica aos adversários de Schopenhauer a seu ver, ou seja, célebres professores que, com sua pretensa filosofia, só têm em vista sua própria notoriedade.

${ }^{46}$ Já introduzida a crítica aos sistemas filosóficos da época, esta sentença se conecta à crítica de Schopenhauer àqueles que não fazem da realidade, mas de meras palavras, o objeto da filosofia, uma das mais difundidas acusações contra as querelas escolásticas. Nisto consiste o abstrair de abstrações e não de intuições: toda a ocupação filosófica consiste em verter o mundo intuitivo em conceitos, mas tal tarefa se degrada quando a filosofia se dedica exclusivamente à discussão de conceitos, ou seja, abstraindo deles novos conceitos pretensamente mais profundos que, na verdade, são cada vez mais vazios.
} 
indissolúveis; logo, eles nunca podem ser o sujeito de um juízo analítico: isto eu tomo como impossível; visto que, quando se pensa um conceito, também se deve poder indicar seu conteúdo. O que se costuma citar como exemplo de conceitos simples não é mais, de modo algum, conceito, mas, em parte, sensações puras, algo como uma cor determinada, em parte, as nossas formas da intuição conscientes $a$ priori; portanto, os elementos últimos do conhecimento intuitivo ${ }^{47}$. Isto é para o sistema de todo nosso pensamento o mesmo que o granito na Geognosia ${ }^{48}$, a última base sólida, que tudo sustenta e além da qual não se pode ir. Para a clareza de um conceito, é requerido não somente que se o decomponha em suas notas definitórias, mas ainda, no caso de serem elas também abstratas, que se possa analisar mais uma vez, e incessantemente, até que se isole o conhecimento intuitivo, consequentemente, até que se mostre a coisa concreta ${ }^{49}$ cuja clara intuição se encobre através das últimas abstrações e, desta maneira, assegura a realidade, como também sobre ela se assentam todas as abstrações mais elevadas. Por isso, não é suficiente a explicação usual de que o conceito esteja claro tão-logo se possa citar suas notas definitórias: pois a decomposição destas notas definitórias talvez conduza sem cessar somente a conceitos, sem que, por fim, intuições jazam no fundo dando realidade a todos aqueles conceitos. Tome-se, p. ex., o conceito "Espírito" e se o analise em suas notas definitórias, "um ente pensante, volitivo, imaterial, simples, [70] que não ocupa espaço, indestrutível”; assim, no entanto, nada é pensado com clareza; porque os elementos deste conceito não se deixam comprovar pelas intuições; pois um ente pensante sem cérebro é como em ente que digere sem estômago. Propriamente claras [Klar] são somente intuições, não conceitos: estes podem ser, no máximo, distintos $[\text { deutlich }]^{50}$. Por isso também, por absurdo que fosse, se relacionou e se empregou "claro e confuso" como sinônimos, explicando-se o conhecimento intuitivo por um abstrato confuso porque só este último seria claro. Inicialmente, Duns Scotus fez isto, mas também Leibniz tinha na base este modo de ver, sobre o qual se

\footnotetext{
${ }^{47}$ Conceitos simples, ao contrário dos compostos, não podem ser divididos em partes, notas definitórias. Schopenhauer não admite denominar "simples" os conceitos cuja análise explicita predicados implicados no sujeito. O "simples", portanto, só pode se referir ao que há de imediato na intuição.

${ }^{48}$ Estudo da estrutura da Terra. Trata-se de uma parte da Geologia, não o mesmo que esta ciência.

${ }^{49}$ Importante observar que, não obstante o objeto intuitivo seja intelectual, enquanto imediato e puro, Schopenhauer o denomina "concreto" em oposição àquilo que dele se abstrai em vista do conceito geral (cf. WWV I/MVR I, § 9). Logo, a "coisa concreta" não é um objeto exterior subsistente, tampouco a coisa em si, mas o objeto real em nosso intelecto, ou seja, o dado do entendimento, sobre o qual como que se acumulam camadas de abstrações e abstrações de abstrações até que seu fundo comum se cubra totalmente. No conceito como tal, portanto, encontramos apenas composições de conceitos; toda definição de um conceito-sujeito remete a novos conceitos-predicados, notas definitórias do primeiro. Este processo analítico, portanto, não se aplica a conceito propriamente ditos "simples".

${ }^{50}$ Aproveita-se, nesta tradução, para apontar para a crítica schopenhaueriana dos dogmas acerca da "clareza e distinção" das ideias da razão. Enquanto a clareza, segundo o autor, pertence à luz da intuição, única capaz de assegurar nossos conhecimentos, conceitos bem formados a partir dela, respeitando-a, ou seja, dotados de tanto conteúdo real quanto possível, podem não ser tão claros, mesmo porque, enquanto abstrações, antes encobrem sua matéria obscurecendo-a. No entanto, podem ser distintos, no sentido de serem bem determinados com relação a outros conceitos de que se diferenciam por meio de suas notas definitórias. Está em jogo o grau de correspondência entre significante (signo linguístico) e significado (o dado do entendimento). Até aqui, todavia, Schopenhauer vinha usando o termo "deutlich" no sentido tradicional de clareza, o que, certamente, não se pode manter em português neste contraste final sem ambiguidade.
} 
assenta sua identitas indiscernibilium: veja-se a refutação do próprio Kant na página 275 da primeira edição da Crítica da razão pura.

Atingiu-se acima a estreita ligação do conceito com a palavra, portanto, da fala com a razão, assentada no seguinte fundamento último. Toda a nossa consciência, com suas percepções interiores e exteriores, tem, via de regra, o tempo como sua forma. Os conceitos, entretanto, formados por meio de abstração como representações completamente universais e diferentes de todas as coisas particulares, têm, nesta qualidade, uma existência, por assim dizer, objetiva, a qual, porém, não pertence à sequência temporal ${ }^{51}$. Por isso, eles precisam se remeter à presença imediata de uma consciência [de algo] individual para que possam, por conseguinte, se inserir em uma sequência temporal, ser puxados, por assim dizer, de volta para baixo ${ }^{52}$, para a natureza da coisa particular, se individualizar e então se tornar ligados a uma representação sensorial [sinnliche Vorstellung]: a palavra. É, pois, [a palavra] o signo sensorial [sinnliche Zeichen] do conceito e, como tal, o meio necessário para sua fixação, isto é, para que se faça uma ideia sua na consciência segundo a forma do tempo e assim se produza uma ligação entre a razão, cujos objetos puramente universais [allgemeine] são os universalia que não conhecem nem lugar nem momento, e a consciência sensorial, simplesmente animal, atada ao tempo. Somente graças a esse meio nos são possíveis e estão disponíveis a reprodução arbitrária, a recordação e a conservação dos conceitos, e primeiramente por seu intermédio as operações de exame com os mesmos, enfim, de julgar, concluir, comparar, delimitar etc. Entretanto, [71] às vezes acontece que os conceitos ocupem a consciência também sem seu signo; de vez em quando percorremos tão rapidamente uma cadeia de conclusões que não pudemos pensar nas palavras em tal tempo. Semelhantes [casos] são só exceções, que supõem uma extensa prática da razão, a qual somente se pôde alcançar por intermédio da linguagem. Como o uso da razão está muito ligado à linguagem, vemos nos surdos-mudos que, se não aprenderam nenhuma espécie de linguagem, mal demonstram mais inteligência do que os orangotangos e os elefantes: pois eles têm a razão quase só em potentia, não em $a c t u^{53}$.

\footnotetext{
${ }^{51}$ Uma vez que, para Schopenhauer, todo objeto real é objeto intelectual, não há problemas em admitir a existência objetiva de conceitos, mas apenas em certa medida. A ressalva se justifica, é claro, não por não haver correspondência entre o conceito e algum "objeto exterior"; tal correspondência é sempre mera ilusão. A justificativa é a relativa falta de conteúdo real na proporção da universalidade do conceito. Portanto, embora se trate de um objeto do intelecto, enquanto tal existente realmente, o mesmo não se pode dizer de seu conteúdo, a que falta a total e segura "concretude" da intuição. Tudo aquilo que é concreto é, por definição, particular, é um isto; enquanto universal, o conceito escapa completamente às determinações temporais e isto mesmo o preserva do emudecimento.

${ }^{52} \mathrm{O}$ conceito, à medida que se torna mais abstrato, se torna mais distante das coisas que se encontram "aqui embaixo", em nossa intuição, ou seja, os objetos particulares do mundo real. Trata-se de fazê-los descerem de sua universalidade de volta para a particularidade do percebido. V. acima nota 44 .

${ }_{53}$ A conclusão acerca dos surdos-mudos é inevitável se se admite que o exercício da razão e mesmo a fixação das experiências depende de conceitos e palavras. Orangotangos e elefantes estão entre os animais mais inteligentes, mas ainda assim desprovidos de razão, de modo que a proximidade intelectual em relação a eles é bastante funesta. É possível que o desenvolvimento de uma linguagem convencional de sinais pudesse servir de contraponto a esta dificuldade, como o próprio autor admite. O caso é análogo, porém menos grave, ao que empiristas como Locke pensavam sobre os limites do conhecimento intuitivo em cegos de nascença, o que também é facilmente compreensível mediante a importância fundamental da visão em sua doutrina e na do próprio Schopenhauer, conforme se vê no capítulo 2. Ainda assim, fica claro
} 
Palavra e linguagem são, portanto, o meio indispensável para o pensamento claro. Porém, como toda máquina, todo meio ao mesmo tempo incomoda e obstaculiza; assim também a linguagem: pois ela força a um apoio seguro, a formas permanentes, as infinitas nuances, pensamentos movediços e modificáveis, e assim ela os fixa, tornando-os prisioneiros. Este obstáculo é removido através do aprendizado de muitas línguas. Pois, com isto, o pensamento é moldado de uma forma para a outra, mas em cada imagem sua se modifica um pouco, liberta-se mais e mais de qualquer forma e invólucro; por meio disso sua mais própria essência entra claramente na consciência e também recupera sua mutabilidade original ${ }^{54}$. As línguas antigas, porém, prestam este serviço muitíssimo melhor do que as novas; pois, graças a sua grande diferença com relação a estas, o mesmo pensamento é expresso agora de maneira totalmente outra, enfim, deve tomar uma forma extremamente diferente; acrescente-se que a gramática mais perfeita das línguas antigas torna possível uma construção mais artística e mais perfeita do pensamento e de suas conexões. Por isso, talvez pudesse um grego ou romano ficar satisfeito com sua língua. Mas quem nada compreende além de um único dos modernos patoás tem esta deficiência logo denunciada na escrita e no discurso, enquanto seu pensamento, amarrado firmemente a formas tão miseráveis, estereotipadas, deve ficar desajeitado e monótono. Entretanto, como tudo o gênio substitui, também isto ${ }^{55}$, como é o caso de Shakespeare.

que a cegueira, do ponto de vista schopenhaueriano não é por si mesma prejudicial à razão quanto à aquisição de experiências e exercício desta faculdade. Por outro lado, uma escrita para cegos é absolutamente incapaz de lhes fornecer uma imensa gama de conteúdos intuitivos fundamentais à vida espiritual. A questão é, em suma, bastante polêmica, pois a dependência da razão face aos sentidos implica sempre algum grau de déficit cognitivo e mesmo experiencial no que concerne a cegos e surdos, uma consequência certamente indesejável na medida em que interpõe ressalvas no princípio de igualdade entre os homens.

${ }^{54}$ De fato, o aprendizado de línguas estrangeiras, quando se dá de modo apropriado, é de grande valor até mesmo para aprimorarmos o conhecimento de nossa própria língua, permitindo-nos utilizá-la com maior precisão. Temos dois bons exemplos disto quando, especialmente em línguas aparentadas, reconhecemos palavras similares ou pouco utilizadas em nosso idioma, aprimorando o vocabulário ou nos fazendo ter consciência de um universo semântico mais amplo em razão dos diferentes usos aqui e acolá ou, ainda, pelo contrário, reconhecermos com maior clareza nuances de sentido, comumente obscurecidas no uso diário. Além disso, especialmente quando se trata de línguas mais estranhas à nossa, aprimoramos nossa compreensão de sintaxe, fundamental para que se capte a organização linguística do pensamento em outra cultura. De um modo ou de outro, o que talvez explique a eventual preferência de Schopenhauer por palavras latinizadas - a exemplo de "Interesse", "Abstraktion" -, o exercício comparativo entre as línguas tende a promover o cuidado no uso dos termos no sentido de melhor explicitarmos o que pretendemos dizer. Assim, o reconhecimento de que nenhuma tradução é uma mera substituição de palavras, em si mesmas apenas arbitrárias, exige-nos um esforço pela captação do pensamento em questão, devendo se reger por ele a versão, pois a ele deve se adequar nosso léxico e nossa gramática.

${ }^{55}$ Burdeau opta por remeter o pronome "dieses" ao obstáculo, assim traduzindo: "Só o gênio pode superar este obstáculo como supera tudo." No entanto, o verbo "ersetzen" tem o sentido de se depositar algo suprindo uma falta, podendo ser uma substituição, uma restituição. Embora não se possa apontar uma incorreção no que a versão francesa expressa, que pode ser mais apropriadamente considerada uma paráfrase, optamos por manter o sentido, que julgamos ser o original, de que a obra de gênio, ainda que escrita nas línguas modernas que Schopenhauer acaba de menosprezar, reduzindo-as a "patoás", é capaz de valer pelo conhecimento de línguas mortas. Ou seja, ler a obra de um gênio recente é como ler a obra de um antigo. A razão disto é que, de acordo com a doutrina do gênio, este é capaz de superar as formas fixas da linguagem corrente, de fato superando-as na medida em que toma por modelo a Ideia, exprimindo uma representação mais imediata da Vontade, da coisa em si. A ruptura de "forma e invólucro" da linguagem se dá especialmente na alegoria poética, sobretudo na poesia trágica, mas, justamente por escapar por completo às amarras de qualquer linguagem padronizada, a música tem o lugar culminante na ordem estética estabelecida por Schopenhauer no livro III. 
Do que eu expus no $\S 9$ do primeiro volume, a saber, que as palavras de um discurso são perfeitamente compreendidas sem representações intuitivas para ocasionar imagens em nosso cérebro ${ }^{56}$, [72] Burke já ofereceu uma discussão corretíssima e muito minuciosamente detalhada em sua Inquiry into the sublime and beautiful [Investigação do sublime e do belo], parte 5, cap. 4 e 557; só que ele tirou disto a conclusão completamente falsa de que nós ouvimos, percebemos e usamos as palavras sem qualquer representação (idea) para ligar a elas; ele deveria, de fato, concluir que nem todas as representações (ideas) são imagens intuitivas (images), mas que justamente os simples conceitos (abstract notions), que devem ser designados através de palavras, e, em virtude de sua natureza, não são intuitivos, - apenas porque palavras comunicam meros conceitos universais, que são absolutamente diferentes das representações intuitivas, na narração de um acontecimento, p. ex., todos os ouvintes receberão o mesmo conceito; só quando, posteriormente, se deseja que eles ilustrem o fato, cada um é combinado a uma outra imagem disto em sua fantasia, a qual difere consideravelmente da justeza que só o testemunho ocular possui. Nisto jaz a razão próxima [nächste Grund] (à qual se associam ainda outras) por que cada fato é necessariamente desfigurado através das sucessivas transmissões [Weitererzählen]: ou seja, o segundo narrador comunica conceitos que ele abstraiu de sua imaginação [Phantasiebilde], aos quais o terceiro, por sua vez, combina uma outra imagem ainda mais desviada, que ele agora novamente muda em conceitos, e assim sucessivamente. Quem estiver secamente satisfeito em ficar imóvel mediante os conceitos que lhe comunicamos e estes passar adiante será o mais fiel repórter.

A melhor e mais razoável discussão que pude encontrar em algum lugar sobre a essência e a natureza dos conceitos está nos Essays on the powers of human mind, de Thomas Reid [Ensaios sobre os poderes da mente humana], Vol. 2, essay 5, cap. $6^{58}$. - Ela foi em seguida desaprovada por Dugald Stewart ${ }^{59}$ em seu Philosophy of the human mind [Filosofia da mente humana]: sobre este, desejo dizer somente, de modo breve, para não dissipar papel por sua causa, que ele pertenceu àqueles tantos que alcançam uma fama imerecida através de favor e amigos; por isso, eu posso somente desagravar não perdendo horas com os escritos dessa mente rasa.

Aliás, que a razão é a faculdade das representações abstratas e o entendimento a das intuitivas, já reconhecera o principesco escolástico Pico della Mirandola, [73] uma vez que, em seu livro De

\footnotetext{
${ }^{56}$ Arthur Schopenhauer's Sämmtliche Werke. Ed. Julius Frauenstädt. Leipzig: Brockaus, 1877. Vol. II, p. 47-48.

${ }^{57}$ Título abreviado do tratado de estética A philosophical inquiry into the origin of our ideas of the sublime and the beautiful (Uma investigação filosófica da origem de nossas ideias do sublime e do belo), de 1757, do filósofo e político irlandês Edmund Burke (1729-1797). Os capítulos a que Schopenhauer se refere, pertencentes à última parte da obra, dedicada especialmente à palavra, tratam, respectivamente, dos "Efeitos das palavras" e de "Exemplos de que palavras podem afetar sem suscitar imagens".

${ }^{58} \mathrm{O}$ quinto ensaio, dedicado à abstração, traz como tema de seu sexto capítulo as opiniões dos filósofos acerca dos universais. A obra em questão foi publicada em 1827.

${ }^{59}$ Filósofo escocês (1753-1828), foi aluno de Thomas Reid em 1771.
} 
imaginatione, cap. 11, distingue cuidadosamente entendimento e razão, esta como a faculdade discursiva peculiar aos homens, e aquela, porém, como o intuitivo modo de conhecer do anjo, aparentado ao de Deus. - Também Spinoza caracteriza muito justamente a razão como a faculdade para formação de conceitos universais: Ética, II, prop. 40, esc. 2. - Não precisam ser mencionados outros casos semelhantes, senão por causa das farsas que todos os filosofastros na Alemanha têm motivado nos últimos cinquenta anos com o conceito de razão, quando, sob este nome, com desavergonhada ousadia, eles quiseram encarnar uma faculdade completamente inventada, um conhecimento imediato, metafísico, chamado suprassensível, sendo, no entanto, a verdadeira razão denominada entendimento, mas o entendimento propriamente dito, muito desconhecido para eles, deixado totalmente de lado, teve suas funções intuitivas imputadas à sensibilidade ${ }^{60}$.

Como em todas as coisas deste mundo, a cada meio de explicação, a cada vantagem, a cada preferência também se vinculam de imediato novas desvantagens; o mesmo vale para a razão, que dá aos homens tão grande primazia sobre os animais; com suas desvantagens peculiares, abre desvios que o animal jamais pode tomar ${ }^{61}$. Através dela alcança-se uma espécie totalmente nova, inacessível ao animal, de motivos, de poder sobre seu querer [Willen] $]^{62}$; a saber, os motivos abstratos, os simples pensamentos, que de maneira alguma são deduzidos sempre da própria experiência, mas muitas vezes só chegam a ela através do discurso e do exemplo do outro, através da tradição e da escrita. Tornado acessível o pensamento, ele já está aberto também ao erro. Cedo ou tarde, todo erro só deve causar danos, e tanto maiores quanto maior ele for. $\mathrm{O}$ erro individual, quem o acolhe, deve expiar uma vez e, muitas vezes, pagar caro: o mesmo valerá na dimensão dos erros em comum de todos os povos. Por isso, para que não se repitam muitas vezes, que cada erro, onde quer que se o encontre, seja perseguido e erradicado como um inimigo da humanidade, e que a erros não se dê nenhum privilégio ou sanção. $O$ pensador deve atacá-los; ainda que a humanidade, igual a um doente cuja úlcera o médico toca, desate logo [74] a gritar ruidosamente ${ }^{63}$. $-\mathrm{O}$ animal nunca pode desviar-se demais do caminho da natureza:

\footnotetext{
${ }^{60}$ Reconhece-se, mais uma vez, a dureza da crítica de Schopenhauer a toda forma de sensualismo na doutrina das intuições, que são, pelo contrário, intelectuais. As intuições do entendimento são atribuídas à sensibilidade pelos "fílosofastros" na medida em que, também nessas formas de racionalismo idealista, o entendimento aparece como faculdade discursiva situada abaixo de uma razão hipertrofiada supostamente capaz de apreender algo como o Absoluto, independente de toda experiência e de toda relação sujeito-objeto. Rompendo, portanto, com toda forma de realismo, seja sensorial ou ideal, o pensamento schopenhaueriano não se reduz nem ao empirismo nem ao racionalismo, apesar de sua notória preferência pelo primeiro em seus recursos à escola britânica, amenizada, porém, por sua estima pelo platonismo. Sua pertença, por assim dizer, não pode ser melhor remetida senão à sua forma peculiar de interpretar o idealismo transcendental proposto por Kant.

${ }^{61}$ Este parágrafo final retoma e desenvolve em grande medida a exposição feita no $\S 8$ do primeiro tomo.

${ }^{62}$ A rigor, a razão não tem poder algum sobre a vontade, segundo Schopenhauer, mas o contrário. A vontade impõe à razão, faculdade de abstrações, a tarefa de produzir representações, objetos do desejo, os quais, por sua vez, se nos convertem em motivos do agir, do sentir e do pensar. Desse modo, para que não se confunda o querer interessado a posteriori com a Vontade em si, sem meta, tampouco com a vontade objetivada de que cada um de nós é o fenômeno, ou seja, nosso caráter inteligível determinado a priori, optou-se pela tradução "querer".

${ }^{63}$ É notável aqui que Schopenhauer não esteja se referindo, em primeiro lugar, a erros de cunho moral, mas, sobretudo, intelectuais, sobretudo os cometidos por filósofos e religiosos. Por meio destas palavras, percebe-se uma justificativa para sua conhecida dureza ao criticar os erros dos pensadores, especialmente os de seu tempo, chegando mesmo a usar de certa
} 
pois seus motivos jazem unicamente no mundo intuitivo, onde somente se vê possível o espaço efetivo: pelo contrário, nos conceitos abstratos, nos pensamentos e nas palavras, tudo só se dá imaginariamente, por conseguinte também se dão aí o falso, o impossível, o absurdo, o sem-sentido. A razão pertence a todos, o juízo a poucos; a consequência é então que o homem fica aberto a ilusões, estando abandonado a todas as quimeras somente imagináveis, que o convencem e que, agindo como motivos para seu querer, o podem conduzir a toda espécie de rebeldia ${ }^{64}$ e tolice, às mais inauditas extravagâncias, bem como às ações mais repugnantes a sua natureza animal. A cultura propriamente dita, na qual conhecimento e desgraça caminham de mãos dadas, só pode ser dirigida a poucos, a ainda menos são os aptos a recebê-la. Para a grande multidão, em toda parte uma espécie de adestramento a substitui: ele é realizado por meio do exemplo, do costume e de determinados conceitos solidamente gravados, com muita antecedência, antes que qualquer experiência, entendimento e julgamento se intrometam no trabalho. Tanto os pensamentos são inoculados que mais tarde, de tão firmemente presos e inabaláveis por qualquer instrução, são considerados muitas vezes, mesmo pelos filósofos, como se fossem inatos. Por estas vias pode-se, com igual esforço, gravar nos homens os mais justos e razoáveis ou ainda os mais absurdos [exemplos, costumes e conceitos], como, p. ex., habituá-los a somente se aproximarem destes ou daqueles deuses com compenetrado tremor sagrado e, mediante o chamado por seu nome, prosternar-se não apenas com o corpo, mas com todo o espírito; a voluntariamente depositarem sua propriedade e sua vida em palavras, em nomes, na defesa dos mais fabulosos caprichos; a ligar arbitrariamente uns e outros às maiores honras e à mais baixa vergonha e por conseguinte a estimar ou desprezar cada qual com fervorosa convicção; a renunciarem a todo alimento animal, como na Índia, ou a comerem ainda quentes e convulsivos os pedaços cortados fora de animais vivos, como na Etiópia; a comerem homens, como na Nova Zelândia, ou a sacrificarem suas crianças a Moloq; a castrarem a si

violência nas palavras: trata-se do dever (Sollen) de todo pensador para com a verdade. Lembremos que se trata aqui do mundo segundo a perspectiva da representação, o mundo do conhecimento. A moral, em Schopenhauer, apenas indiretamente dirá respeito ao saber e, em tal caso, no que concerne às doutrinas e opiniões que vêm ou possam vir a sancionar erros, falseando assim a Ética. A moralidade, ao contrário, relaciona-se com nosso modo de ser, é uma questão de fundo ontológico, nisto residindo a tematização do egoísmo e da compaixão precisamente no livro IV, no qual se aborda o mundo segundo a perspectiva da Vontade, da coisa em si.

${ }^{64}$ Traduz-se por "rebeldia" a palavra "Verkehrtheiten" apelando para a riqueza semântica do termo, que ao mesmo tempo exprime as noções de erro, reversão, troca de posição, improcedência e mau humor, estando em jogo a ideia de um movimento de contrariedade, de voltar-se contra algo, um giro pelo qual, neste caso, se desvia da ordem natural das coisas. Trata-se de um uso abusivo da razão pelo qual se provoca um desvio. Como se pode ler no $\$ 9$ do primeiro tomo, a própria lógica é inútil no que concerne ao ensino do raciocínio, podendo mesmo levá-lo à confusão - seu valor não está em ensinar a pensar, mas em esclarecer as estruturas do pensamento, vinculando-se à teoria do conhecimento. Traduzir, por exemplo, por "loucura", como faz Burdeau, incorre no risco de restringir o sentido da palavra alemã a atos meramente irrazoáveis e impulsivos, deixando de lado aqueles baseados em motivações bem determinadas e conscientes. Do mesmo modo, não se inclui no universo de loucura, como faz Burdeau, a palavra "Thorheiten", omitida pelo tradutor francês, que remete a ingenuidade e falta de atenção aos fatores que estão em jogo. Mais adiante, contudo, "Verkehrtheiten" volta a ser utilizada em um sentido mais estrito, relativo às "loucuras" cometidas pela humanidade em nome de fictícias determinações religiosas que, de todo modo, não deixam de consistir, aos olhos de Schopenhauer, em atos de rebeldia contra nossa "natureza animal" - i.e. intuitiva - e, por isso, dignas de repúdio, mas sem se tratar ainda de loucura propriamente dita, mencionada apenas na sentença final deste capítulo. 
mesmos, a voluntariamente na pira funerária se [75] precipitarem, - em uma palavra, o que se quiser. Daí as Cruzadas, os excessos das seitas fanáticas, milenaristas e flagelantes, perseguições de hereges, Autos de Fé, e o que sempre mais ainda expõe o longo registro dos desvarios ${ }^{65}$ humanos. Para que não se pense que somente séculos tenebrosos produzam tais exemplos, acrescento um par de exemplos mais recentes. No ano de 1818, 7.000 milenaristas de Würtemberg mudaram-se para a vizinhança do Ararat; especialmente porque Jung-Stilling anunciara que o novo Reino de Deus deveria despontar naquele lugar. ${ }^{66}$ Gall conta que em seu tempo uma mãe matara e assara seu filho para, com sua gordura, curar os reumatismos de seu marido ${ }^{67}$. O lado trágico dos erros e prejulgamentos jaz na prática, o cômico é reservado ao teórico: tome-se, p. ex., apenas três homens firmemente persuadidos de que o sol não é a causa da luz do dia; neste caso pode-se esperar para ver que dentro de pouco tempo isto valerá como convicção universal. Hegel, um repugnante charlatão sem espírito e rabiscador de absurdos sem precedentes, foi proclamado na Alemanha, como se sabe, o maior filósofo de todos os tempos, e muitos milhares acreditaram firmemente por vinte anos, e mesmo fora da Alemanha a Academia Dinamarquesa, por sua fama, manifestou-se contra mim e quis fazê-lo valer como um summus philosophus. (Veja a este respeito o prefácio para o meu Problemas fundamentais da ética.) ${ }^{68}-$ Estas são, enfim, as desvantagens que estão ligadas à existência da razão, as vias da raridade do juízo. A elas junta-se ainda a possibilidade da loucura: animais não se tornam loucos; apesar de os carnívoros estarem expostos à raiva e, os herbívoros, a uma espécie de fúria ${ }^{69}$.

\footnotetext{
${ }^{65}$ Ver nota anterior.

${ }^{66}$ Illgens Zeitschrift für [die] historische Theologie [Revista de teologia histórica, de Christian Friedrich Illgen], 1839, 1. ed., p. 182. (N. do A.) O Monte Ararat, de acordo com o livro das Gênesis, é onde teria encalhado a arca de Noé após a baixa das águas do dilúvio, tendo sido, portanto, o local de início do novo mundo pós-diluviano.

${ }^{67}$ Gall et Spurzheim, Des dispositions innés[de l'âme et de l'esprit, du matérialisme, du fatalisme et de la liberté morale, avec des réflexions sur l'éducation et sur la législacion criminelle] [Sobre as disposições inatas da alma e do espírito, sobre o materialismo, o fatalismo e a liberdade moral, com reflexões sobre a educação e sobre a legislação criminal, de F.J. Gall e G. Spurzheim], 1811, p. 253. (N. do A.)

${ }^{68}$ Schopenhauer refere-se à conhecida reprovação, tornada anedótica, de sua monografia Sobre o fundamento da moral pela Sociedade Real Dinamarquesa de Ciências de Copenhague, em 1840, por ocasião de um concurso em que fora o único concorrente. O julgamento termina com as seguintes palavras, conforme a tradução de Maria Lúcia Cacciola: "Também não se pode calar o fato de que o autor menciona vários excelentes filósofos contemporâneos de modo tão indecente, o que provoca justa e grave aversão". Embora o que os pareceristas digam antes disso trate do conteúdo da tese exposta na monografia, estas palavras finais deixam claro que o concorrente não faria jus ao prêmio a despeito de seu mérito filosófico. Sabemos também por Kierkegaard da hegemonia hegeliana na Dinamarca, da qual se torna um grande crítico em seu país. No ano precedente, Schopenhauer havia sido premiado pela Sociedade Norueguesa de Ciências de Drontheim em virtude de sua monografia Sobre a liberdade da vontade. Em 1841, ambos os textos seriam reunidos para publicação em um único volume intitulado Os dois problemas fundamentais da ética.

${ }^{69}$ Infelizmente, estas palavras finais são bastante inconclusivas. Claro está que, para Schopenhauer, a loucura propriamente dita é uma das desvantagens da razão, de ser dotado desta faculdade e capaz das representações que lhe são próprias, de modo que a loucura não seria encontrável nos animais não-humanos. Trata-se, também certamente, de supor que a loucura vai além dos desvarios movidos por convicções destituídas de juízo, podendo estar relacionada a um estado de descontrole, de "perda da razão", que, por sua vez, só acometeria seres racionais na medida em que suas motivações pertenceriam ao mundo abstrato. Os estados de descontrole que eventualmente acometem os animais restritos ao mundo intuitivo remeteriam, antes, a meros sentimentos e instintos. Falta, de todo mundo, clareza na relação vista por Schopenhauer entre loucura e razão, o que seria de grande interesse, bem como, e não menos interessante, considerar em que consistiria o estado de hostilidade, melancolia etc. que eventualmente transformam drasticamente o comportamento de animais que, por exemplo, passam por situações profundamente traumáticas. Seriam, neste último caso, meras disfunções neurológicas? Mas não se
} 
DAX MORAES

Recebido: $13 / 11 / 12$

Received: $11 / 13 / 12$

Aprovado: $21 / 12 / 12$

Approved: $12 / 21 / 12$

poderia reduzir também a isto a loucura humana? 